Article

\title{
The 'Expo' and the post-'Expo'. The role of public art in urban regeneration processes at the late 20th century
}

\author{
Rita Ochoa ${ }^{1}$ \\ 1 UrbinLab, CIAUD-UL/UBI, Calçada Fonte do Lameiro, Covilhã, 6201-001 Portugal; rita.ochoa@ubi.pt
}

\begin{abstract}
In 1998, the Lisbon Universal Exhibition - Expo'98 - led to an urban regeneration process on Lisbon's waterfront. Following other cities, this event was a pretext to replace a depressed area and to re-connect it with the river, through the creation of a set of new spaces for common use along the water. For them, it was promoted a public art program, which can be considered quite innovative in the Portuguese context, and that resulted in a monumentalisation of Lisbon's eastern riverfront, later extended to other areas.

Behind this framework, this article aims to debate the relations between public art and the dynamics of urban regeneration at the end of the 20th century. For that, it will analyse: 1) the Expo' 98 's public art program, comparing its initial assumptions with the final results; 2) the impact of this program, through the identification of public art's placements before (1974-1998) and after (1999-2009) the event.

As a result, it is possible to find that the placement of public art reveals the spaces that were "conquered" to the port system, and a dialectic between functional/economic and leisure/symbolic values. It is concluded that public art had a significant role in the urban processes of the late 20th century, which is quite evident in a discourse that considers it as a qualifying factor of urban space and a mean of economic and social development.
\end{abstract}

Keywords: public art, Lisbon, Expo'98, urban regeneration, waterfront areas.

\section{Introduction}

In 1998 took place the last universal exhibition of the millennium in Lisbon, the Expo'98, which gave rise to an urban regeneration operation with strong impact in the city, particularly in its east part.

This type of dynamics was very frequent at the late 20th century. Worldwide, international events - Grand Projects as International Exhibitions, Olympic Games and others - were pretext for urban regeneration processes that replaced entire obsolete areas, with own resources (in Europe, often with the help of European Union programs). These dynamics took place in a spirit of aestheticising of city life and landscape, which did not stay only with the disciplines of architecture and urbanism, but also with the visual arts.

Public art assumed an important role in these processes, as an urban qualification issue, even of economic and social development of cities [1]. Therefore, several cities hosted public art programs, investing on a policy of attracting prestigious artists, either directly with art galleries, or through commissioning, where "leading international artists and architects leave their mark in cities, generating new elements for their valorisation in the context of global competition" [1] (p. 26) 1 .

Frequently, these processes were developed in port cities, where waterfronts had undergone relevant changes over time. From the post-industrial period and due both to the de-industrialisation and the technological changes in maritime transportation, several spaces become empty, giving rise to obsolete terrains. From the last decades of the 20th century, great interventions took place in those areas, which, despite their differences, seem to have in common the aim of reintegrating the waterfronts and the "rescue" of those areas for the citizens, through the creation of new public spaces.

\footnotetext{
1 "artistas y arquitectos internacionales de primera línea dejan su marca en las ciudades, generando en el contexto de la competencia global nuevos elementos para su valorización”.
} 
In this context, waterfronts become privileged spaces for the placement of public art. ${ }^{2}$ In turn, the placement of public art becomes a way to intensify their symbolic nature and to emphasise their monumentality. ${ }^{3}$

With about 17 kilometers long, the Lisbon's waterfront has been occupied by various artistic interventions. Here, the port assumes a linear occupation model [4] and its infrastructures still occupy a substantial part of those 17 kilometers. In this perspective and due to the inherently public character of public art, its placement can be seen as an indicator of the areas where port occupation was interrupted, the "'breaches" interrupting this arid linearity and allowing an accessibility to the banks" [5] (p. 112)4 - that is to say, the public spaces that are "conquered" to the port (Fig. 1). In a more general understanding, public art interventions can reveal, throughout the city, the priority areas of intervention, and Lisbon's waterfront was certainly one of those.
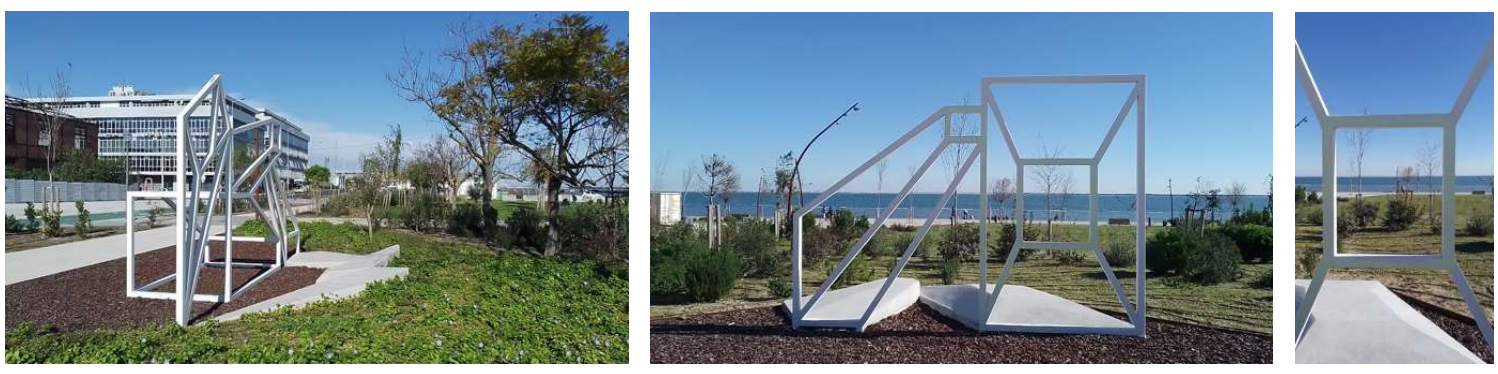

Figure 1. Parque Ribeirinho Oriente [Filipa Cardoso de Menezes and Catarina Assis Pacheco]: "Esculturas Solares" [Natália de Mello] in new public spaces on Lisbon waterfront, revealing the openings in the linearity of the port. Source: (Ochoa, 2020)

\section{Materials and Methods}

2.1 Assumptions and results of the Expo'98 public art program

The main theme of Expo'98 was "The Oceans, a Heritage for the Future", celebrating the Discoveries and the Portuguese achievements around the world. As said before, the Exhibition was also a pretext to regenerate a vast slice of territory, in Lisbon's eastern area, that was characterised by an extensive range of obsolete and unoccupied terrains and industrial spaces. It was intended to transform all this area into a new centrality [6], to remain after the end of the Exhibition ${ }^{5}$. Therefore, the developed urban plan ${ }^{6}$ was not limited to the Expo'98 venue, but it included its surroundings and integrated a set of projects of cultural equipments, leisure areas and new housing extents. Another objective of the urbanisation plan was to reconnect the Tagus River with the city, through the creation of new public spaces along the water.

At the same time, the organisation of the event decided to implement a set of public art interventions to qualify those new spaces. 24 national and international artists were invited and were given freedom to design their artistic projects. This was clearly an opportunity to test new artistic intervention models to Lisbon's public space.

The program was curated by António Manuel Pinto and António Mega Ferreira. The artistic works were developed along with the Exhibition project, according to the needs of the several interventions. In fact, there was not exactly a defined program, "so, it is less a program than a list of interventions that found their reason not in a specific sectoral strategy aimed at the visual arts. But much in its placement in space and in the discourses, that would give body to the Expo'98 venue" [7] (p. 9)7. Nevertheless, there was a common theme for the artists, the same of the Exhibition, and many of the interventions focused on the imaginary of water.

\footnotetext{
${ }^{2}$ In 2010, there were 173 elements of public art in Lisbon waterfront [2].

${ }^{3}$ However, it is important to remember that the monumentalisation of the waterfront is, in many cities, conflicting. As Kostof states, "the issue of monumentalising the water's edges is complicated by functional arguments. To the extent that a river is a working watercourse with a port, there is a definite conflict between those who make use of it for trade-related activities and those who would turn into a work of art" [3] (p. 41).

4 "'brèches" interrompant ce linéaire aride et permettant une accessibilité des citadins aux berges".

${ }^{5}$ Currently, this area corresponds to a consolidated area of the city, called "Parque das Nações".

6 “Plano de Urbanização da Zona de Intervenção da Expo'98" (PUZI), 15th July 1994.

7 "por isso ele é menos um programa que uma lista das intervenções que encontraram a sua razão de ser não numa estratégia sectorial específica destinada às artes visuais. Mas muito na sua concreta inserção no espaço e nos discursos que haveriam de dar corpo ao recinto da Expo'98".
} 
In the proposals' catalogue, António Manuel Pinto highlighted the possibilities that the new spaces were conducive "to the most innovative urban experiences, starting from the desire to introduce new philosophies of space occupation" [8] (p. 13 $)^{8}$. The importance of public art as an urban qualification issue was here assumed, through an understanding of the work together with the place, in an integrated level, "we have not merely moved existing works of art to a public place, nor is that what makes it an artistic object an object of public or urban art (...). An object of public art is specifically designed for that situation" [9] (p. 177)9.

Also, the followed strategies consisted of promoting relationships - through scale, framings - with the place, "There was a conversation with the artist in which the object was defined, we considered the height, the space where it was placed, the way it would be seen from various points" [10] (p. 21) ${ }^{10}$. It was intended to explore physical but also social relationships, humanising the landscape and boosting urban experiences, "artistic projects that influenced the experiential practices of the territory" [8] (p. 13) ${ }^{11}$

On the other hand, the conventional models of art integration were questioned, namely the model of the statuary in the center of a square. Public art was refused as a bibelot, as a decorative element or an accessory of the urban fabric [11], to be understood as artistic intervention, promoting the experience of the territory, not only in sculptural interventions, but also in the design of new topographies, pavements, coatings, among others (Fig. 2).
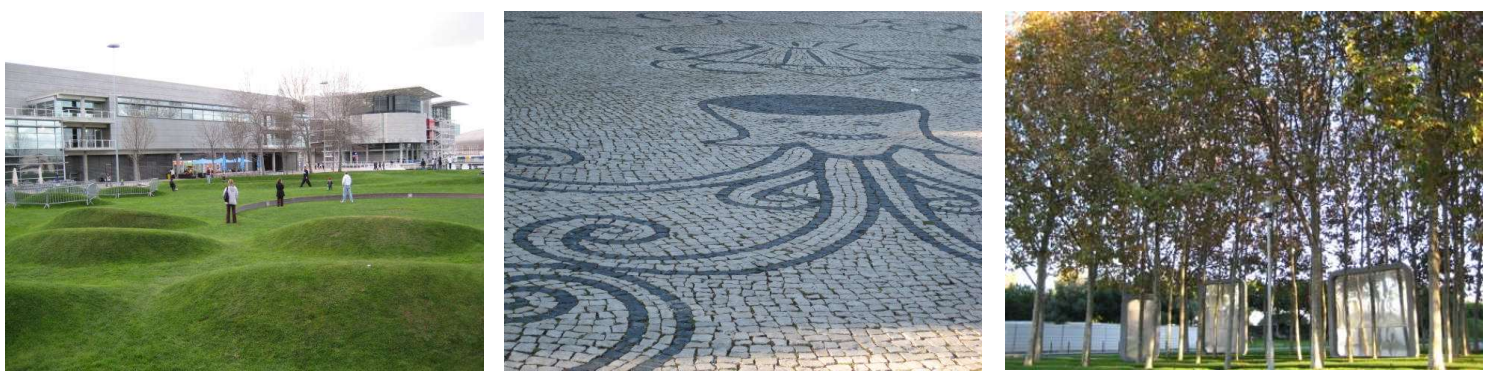

Figure 2. Works of Expo'98 public art program (from left to right: "Jardim das Ondas" [Fernanda Fragateiro and João Gomes da Silva]; pavement [Pedro Proença]; untitled [José Pedro Croft].

Finally, it was intended to understand all the interventions in an integrated logic. In addition to promote relationships with its context, each work should be a reference in the urban fabric. According to António Mega Ferreira, [the urban art program of Expo'98] "represents a sum of the parts that are indispensable elements for the construction of the landscape, not as decorative figures, but as topoi of a strategy of deconstruction and reconstruction of urban space that culminates in the Expo'98 venue but inevitably extends throughout all the intervention zone" [7] (p. 9)12 (Fig. 3).
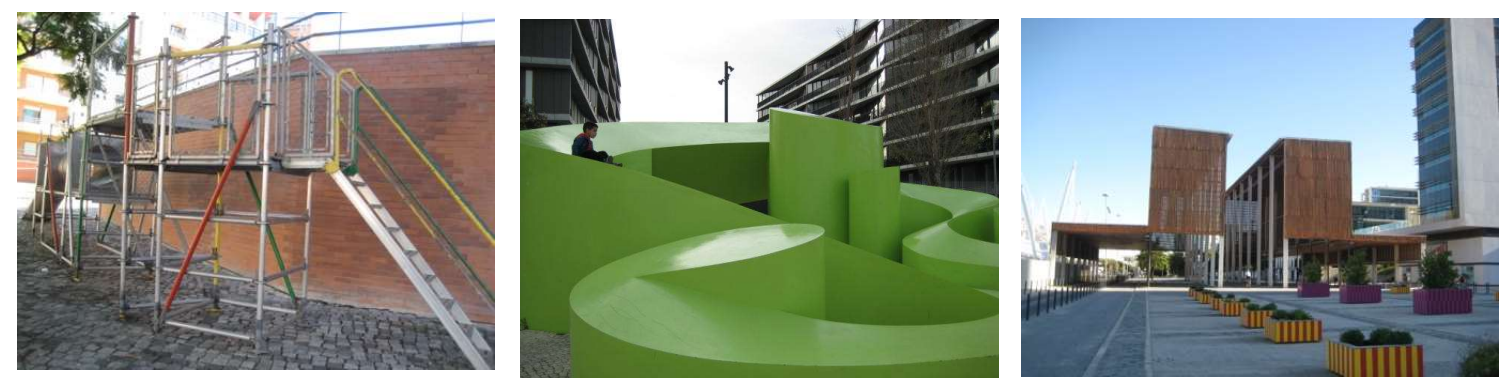

\footnotetext{
8 "às mais inovadoras experiências urbanas, partindo do desejo de concretizar novas filosofias de ocupação de espaço".

9 "não nos limitámos a deslocar obras de arte existentes para um local público, nem é isso que torna o objecto artístico um objecto de arte pública ou urbana (...). Um objecto de arte pública é pensado de raiz para essa situação".

10 "Havia uma conversa com o artista em que se definia a peça, considerávamos a altura, o espaço onde se inseria, a forma como seria vista de vários sítios".

11 "projectos artísticos que influíssem nas práticas vivenciais do território".

12 "representa a soma de partes que se foram afigurando como elementos indispensáveis à construção da paisagem, não como figurações decorativas, mas como topoi de uma estratégia de desconstrução e reconstrução do espaço urbano que culmina no recinto da Expo'98 mas se prolonga, inevitavelmente por toda a zona de intervenção".
} 
Figure 3. Works of Expo'98 public art program (from left to right: "Kanimambo" [Ângela Ferreira]; "Cursiva" [Amy Yoes]; porta norte [Manuel Taínha].

Regarding the interventions' subject, one of the main concerns of the commissioners' team was the relationship of urban art with the past, "We did not want a pass-through discourse (...) it was an interesting work: to integrate a strong component of urban art in the new spaces, contrary to the temptation of filling it with references related to the History of Portugal" [10] (p. 21) $)^{13}$.

In a context in which art in the public space was undervalued and quite limited both spatially and plastically, these assumptions favored the commission of a set of projects that reflected the Portuguese artistic contemporaneity. However, this contemporaneity was limited to a restrict group of artists that, due to foreign experiences or influences, had break with the art of the Estado Novo period. These were the names that were invited to this unique moment of recognition of the Portuguese public sculpture [12], that matched with the possibility to create a public art project, for the first time in Portugal.

However, despite the glow of the program's initial assumptions, many of the solutions felt short of what was really expected. In general, most of the artistic projects did not achieved the proposed objectives and did not surpass the character of space's descriptivism [13,14]. Although this was a unique opportunity to question public art and its relationship with the place, many of the results did not motivate any processes of spatial/social articulation with the contexts. And many of them, although adopting a more contemporary language, were not beyond the model of the statuary in the center of a square, that was so criticised.

\subsection{Symbolic impacts of the Expo'98 public art program}

Despite having fallen short of the expected results - and especially regarding integration -, the Expo'98 public art program had the merit of bringing to the Portuguese context and to Lisbon the debate about art and public space.

One of the strengths of Expo'98, also a cause of its success [9], was the quality of the places, the gardens, the riverside promenade and its leisure spaces. At the same time, the public art program transformed the eastern waterfront into one of the most densely monumentalised areas in Lisbon [2]. Therefore, it is interesting to observe an increase of artistic interventions in public space, in the following years.

Figure 4 shows the placements of public art both in the waterfront and in the urban axes of articulation with the waterfront (the transverse axes) over 35 years, more precisely between 1974 and 2009.14

Between 1974 and 1980, there were no public art placements. ${ }^{15}$ The first identified work dates to 1981, the monument "Ao emigrante português" [To the Portuguese emigrant], next to the Santa Apolónia Railway Station. ${ }^{16}$

Between 1981 and 1997, there were between 1 and 3 placements per year, except for 1982 and 1992 without any placements, and 1994 with 6 placements - all in the western Lisbon, probably due to the event "Lisboa 94 Capital Europeia da Cultura", which encompassed a vast artistic program and a set of cultural spaces.

\footnotetext{
13 "Não pretendíamos um discurso passadista (...) foi um trabalho interessante: integrar uma forte componente de arte urbana num espaço recémnascido, sem cair na tentação de o rechear com referências à História de Portugal".

${ }^{14}$ This survey results from a more comprehensive research, the PhD Thesis Cidade e Frente de Água. Papel Articulador do Espaço Público [2].

${ }^{15}$ It is important to note that there may exist elements which are no longer in the public space. According to the defined rationale, only the elements that were in the studied spaces during the fieldwork period (2008-2010) were considered.

${ }^{16}$ Showing the importance of this area in view of the remaining eastern riverfront, still a territory predominantly occupied by industries, port infrastructures and housing for the working class.
} 


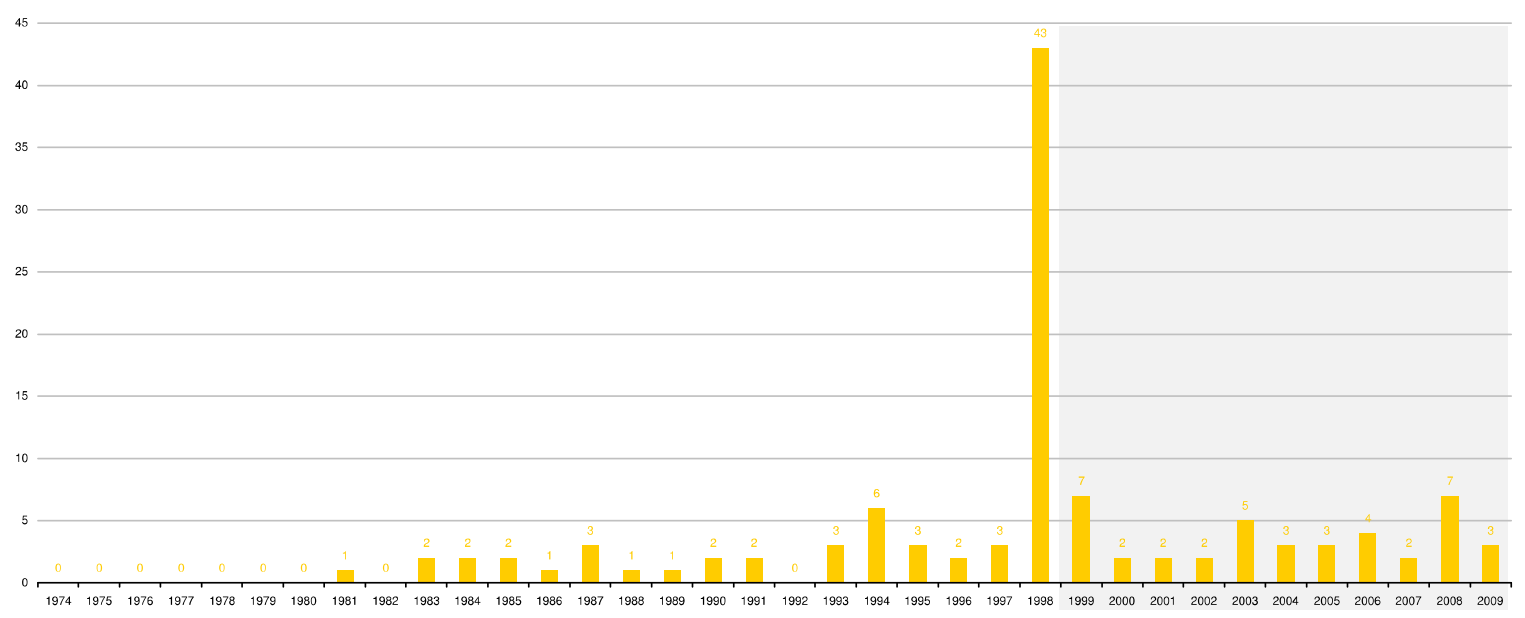

Figure 4. Placement of public art in Lisbon waterfront and in the 20 studied transverse axes between 1974 and 2009.

As expected, the 1998 was an exception in the placement of public art, with 43 new interventions, being most of them in the scope of Expo'98. The way public art was addressed and the results of the urban regeneration process - a new and highly densely monumentalised area - certainly gave an impulse on the placement of a set of works, in the postExpo'98 period.

Between 1999 and 2009, there was a significant increase of public art: between 2 and 7 new elements, per year. In all this period, there were 40 new placements, 19 in the western area/historical center and 21 in the eastern area of the city. Among these 21 placements, 16 of them were in "Parque das Nações", specifically in the territory that hosted the Exhibition. If until this event, the eastern part of Lisbon had very few public art, it is now one of the most densely occupied areas in the city. However, there was no such increase in the surrounding areas, namely in Chelas or Olivais (Norte and Sul) neighborhoods, which is symptomatic of the lack of contamination [9] from Expo'98 to the rest of the eastern Lisbon.

\section{Discussion/Results}

Among the 40 works placed on Lisbon's waterfront and in the transverse axes in the decade of 1999-2009, there are several monuments focusing on emblematic themes and with strong symbolic character. Works as " 500 anos da partida de Pedro Álvares Cabral para o Brasil" [a celebration of the 500 years since Pedro Álvares Cabral's departure to Brazil], "A guitarra portuguesa" [the Portuguese guitar, a tribute to the Fado singer Amália Rodrigues], or the work with the name of the city "Lisboa, aos construtores da cidade" [Lisbon, to the city builders] - had positioned near the water. On the other hand, in the universe of those 40 public art elements, only 5 did not occupied the waterfront.

Thus, it is possible to perceive that, beyond being privileged spaces for the placement of public art, the waterfronts are also a context for monuments of important symbolic character.

It is also possible to understand that all these placements translate a chronology of the interventions in Lisbon waterfront and the openings on the port structure, in that period. They also report on the followed urban policies and in a way of thinking the city and public space, in that period.

For example, in Parque das Nações, it is possible to identify a tendency to associate public art to buildings, in various ways, such as in the facades, in sculptures that stand out from the main volumes, or in transitional spaces such as entrances, patios and terraces - physically accessible, but often not visible from the public space.

Although the impulse was given by the Expo'98 public art interventions, this way of bringing art to private/ non accessible spaces or simply associated to buildings does not follow the same logics of that program, in which the works should relate to urban design, public space and to the specificities of its contexts, particularly with the waterfront.

The logics of placements of the 1999-2009 period in "Parque das Nações" also seem distinct from the logics of placements in other areas of the city: in the first case, most of the works do not explore relationships with the place or any rememorative character. There is even a tendency towards a more abstract language, distant from the concept of monument. 
In the artistic works of the post-Expo'98, is possible to perceive an understanding of public art from an aesthetic point of view - of art in the public space and less of public art [15]. And somehow more elitist (it is symptomatic that most of them develop a more abstract language) not assuming the relationship with the public space, therefore, its public condition. On the contrary, they settle in housing buildings, favoring the access to artistic interventions exclusively for their residents. ${ }^{17}$ The positioning of artistic elements in the residential spaces, with little or any contact with the public space, perhaps subverts its own meaning as public art.

\section{Conclusion}

Although having generated a new centrality and the replacement of an extensive area of depressed spaces and buildings, the Expo'98's urban project had failures: its insularity [17]; the lack of synergies with the surrounding areas, particularly with problematic contexts such as Chelas, or even Olivais; and the housing project aimed to social classes with greater purchasing power - a large private condominium [18] - despite the general poor architectural quality. It was also criticised the excessive density, and the not investing in more experimental models and ways of doing [9]. In the field of public art, the program developed in the scope of the Expo'98 gave rise to a monumentalisation of all these new areas, associating symbolic elements with spaces of water fruition. At the same time, it played an important role in a way of understanding the city and public space, that decisively influenced subsequent projects.

However, most of the works did not explore the integration with the place, which could have been achieved if it was assumed a more consistent interdisciplinary work, a priori [9]. With few exceptions, the initially requested collaborative approach was not adopted in the scope of the design processes. As Campos Rosado concluded later (in [9] p. 177), "the public art program we proposed, for the entire area of intervention, was not very new (...) it should have participated earlier in the level of the design of the spaces and in the detail plan. Otherwise, the presence of art is very traditional locating a piece in one place..." 18

In the decade after the event (1999-2009), there was an increase of the artistic interventions in the city, particularly in the waterfront. But in many cases, the interventions subverted the public logic, confined to buildings and with the purpose to economically value the housing projects. In fact, the interventions of the post-Expo'98 reflect a certain exhaustion of the previous policies and even of public art.

In recent years, the attention has been focused on the label of "urban art", moving a specialized and international audience, and generating an important economic movement, especially if cities have a curating policy, as the case of the action of the Urban Art Gallery (GAU) in Lisbon [1]. Despite the interest of these practices, in many cases it still does not exist an ability to provoke relationships with the place, and the artistic interventions are exhausted in the work itself.

In the opening of new possibilities for public art, it is important to consider new ways of thinking and making the city, with the people who inhabit it. And do not give up of more participated and interdisciplinary models, where art can exist in an integrated way and not with a decorative role. The new possibilities of public art can arise from the intersection between the specificities that characterise them and the complexity of the relationships that define the current urban life.

\footnotetext{
17 This tendency of placing urban art in Parque das Nações is related to prestigious housing strategies, in the same line of the design of buildings by renowned architects. It is interesting to note the Website of Portal of Nations [16] (consult. Jul 21): "In Parque das Nações the art is in the streets, in the squares, in the gardens, under our feet. It is worth seeing up close the works of urban art that talented artists left in Parque, turning it into an openair museum. Discover them step by step!" [No Parque das Nações a arte está na rua, nas praças, nos jardins, debaixo dos nossos pés. Vale a pena ver de perto as obras de arte urbana que talentosos artistas deixaram no Parque, transformando-o num museu a céu aberto. Descubra-as passo a passo!"].

18 "o programa de arte pública que propusemos, para toda a área de intervenção, não foi muito novo (...) deveria ter participado mais cedo em opções ao nível do desenho dos espaços e plano de pormenor. De outro modo, a presença da arte é muito tradicional - colocar uma peça num sítio..."
} 


\section{References}

1. Remesar, Antoni (2019). De la escultura al post-muralismo. Políticas de Arte Público en procesos de Regeneración Urbana. On the Waterfront, 61, 3-65.

2. Ochoa, Rita (2012). Cidade e frente de água. Papel articulador do espaço público. Thesis (PhD in Public Space and Urban Regeneration), Faculdade de Belas Artes, Universidade de Barcelona.

3. Kostof, Spiro (2005) [1992]. The city assembled. The elements of urban form through history. London: Thames and Hudson.

4. Wilson, Ariane (2001). Quand l'urbain prend le large. L'architecture d'aujourd'hui, 332, 28-35.

5. Chaline, Claude (Dir.) (1994). Ces ports qui créèrent les villes. Paris: L'Harmattan.

6. Portas, Nuno (1998). Interpretazioni del progetto urbano: L'emergenza del progetto urbano. Urbanística, 110, 51-60.

7. Mega Ferreira, António (1998). Figuras Livres. In Parque Expo'98 (Org.), Arte Urbana. Urban Art (pp. 8-11). Lisboa: Parque Expo' 98.

8. Pinto, António Manuel (1998). Arte urbana: entre o espaço público e o espaço humano. In Parque Expo'98 (Org.), Arte Urbana. Urban Art (pp. 12-15). Lisboa: Parque Expo'98.

9. Brandão, Pedro (2011). O sentido da cidade. Ensaios sobre o mito da imagem como arquitetura. Lisboa: Livros Horizonte.

10. Salgado, Manuel (s/d.). Espaços Públicos. Lisboa: Parque das Nações.

11. Carvalho, Anabela (Dir.) (2005). Estatuária e escultura de Lisboa. Roteiro. Lisboa: Câmara Municipal de Lisboa/Departamento de Património Cultural/Divisão de Património Cultural.

12. Santiago, Catarina (2013). Do monumento à arte pública em Portugal no séc. XX. Dissertation Thesis (Master in Art and Heritage Sciences), Faculdade Belas Artes, Universidade de Lisboa.

13. Traquino, Marta (2010). A construção do lugar pela arte contemporânea. Porto: Edições Humus.

14. Brito Alves, Margarida (2014). À procura de um contexto: arte pública em Lisboa na segunda metade do século XX. Revista de História de Arte, 11, 318-329.

15. Remesar, Antoni (2005) [1997]. Public Art: Towards a Theoretical Framework. In Antoni Remesar (Ed.), Urban regeneration. A challenge for public art (pp. 128-140). Barcelona: Universidade de Barcelona.

16. Site Portal das Nações. Descobre o Parque das Nações. Consulted September 2019. http://www.portaldasnacoes.pt/

17. Matias Ferreira, Vítor (1999). E depois da Expo'98, a cidade à beira mar plantada? In Vítor Matias Ferreira \& Francisco Indovina (Eds.), A cidade da Expo'98. Uma reconversão da frente ribeirinha de Lisboa? (pp. 313-327). Lisboa: Bizâncio, 1999.

18. Gato, Maria Assunção (2010). Viver no Parque das Nações. Espaços, Consumos e Identidades. Thesis (PhD in Cultural and Social Anthropology), Universidade Nova de Lisboa. 